\title{
Impact of Granite Quarrying on the Health of Workers and Nearby Residents in Abeokuta Ogun State, Nigeria
}

\author{
*Oguntoke Olusegun; Aboaba Adeniyi and Gbadebo T. Adeola
}

\begin{abstract}
The present paper monitored levels of suspended particulate matters in the ambient air in and around selected quarries and analyzed the prevalent health problems suffered by nearby residents and quarry workers. It also assessed the residents' awareness of the negative implications of living in close proximity to quarry sites. Suspended Particulate Matter (SPM) meter was employed to monitor the level of particulate matter $\left(\mathrm{PM}_{10}\right)$ within and around five quarry sites selected for this study. The data collected from hospital records of quarry workers portrayed their health profile while the prevalent health problems of the nearby residents were elicited from a questionnaire survey conducted in two selected neighbouring communities of quarries. Results of the study showed that the highest mean SPM levels among the selected quarries vary between $26.03 \pm 1.36 \mathrm{mg} / \mathrm{m}^{3}$ and $11.03 \pm 1.52 \mathrm{mg} / \mathrm{m}^{3}$. SPM levels declined significantly $(p>0.05)$ with distance from the drilling and crushing locations at each of the quarry sites. At 25 metres away from the quarry sites, mean SPM levels reduced drastically to $4.85 \pm 0.20 \mathrm{mg} / \mathrm{m}^{3}$ and $3.67 \pm 0.40 \mathrm{mg} / \mathrm{m}^{3}$. Both psychological and health problems suffered by nearby residents include shock (46.0\%), nasal infection (29.2\%), and asthma (4.6\%). The quarry workers suffered predominantly from cough $(26.0 \%)$, catarrh $(20.0 \%)$ and sinusitis (15.0\%). Although, the residents of neighbouring communities are aware of risks associated with living near quarry sites, their general low socio-economic status made them incapable of taking any decisive measure towards relocating elsewhere. Approval for quarry operation should mandate environmental impact assessment and ensure strict implementation of outlined mitigation measures so as to guarantee environmental sustainability.
\end{abstract}

Key words: Quarrying impact, air pollution, particulate matter, occupational health, Nigeria

\section{Introduction}

The complex mixture of gases that make up the earth atmosphere has been altered much more significantly in the recent time. Human activities that range from domestic energy utilization to large scale industrial operations are largely responsible for this undesirable status of atmospheric constituents due to addition of pollutants. Air pollution is a major environmental problem affecting both the developing and the developed countries of the world. The effects of air pollution on human health are very complex as there are different sources; thereby producing varying effects (www.edugreen.teri.res.in).

Although industries such as power plants, cement, refineries, petrol-chemicals and mines have been identified as major sources of air pollutants, the emission of particulates is quite outstanding from quarries. Generally, the effects of dust emission from quarries have both micro and regional dimension. Air pollution and ground vibration arising from blasting, crushing and emission of noxious gases have negative impacts on human health and well-being.

Quarrying products are increasingly demanded for industrial, domestic, agricultural and other purposes so as to satisfy the needs of the rapidly growing population. Quarrying operations generally involve removal of over burden, drilling, blasting and crushing of rock materials. The various impacts produced by these operations are both size and locations dependent. Manifestations of specific impacts are on the air, water, soil, earth surface, floral and fauna, and human beings (Areola, 1991; Enger and Smith, 2002). Apart from land degradation, other negative impacts of quarrying includes swamp creation, deterioration of ground water, erosion of soil, noise and percussions from rock blasting, generation of dust, smoke and fumes; production of noxious gases and ground vibration. Suspended particulate matter is quite outstanding among all pollutants emanating from quarrying operations (USEPA, 2008).

Solid materials in the form of smoke, dust and also vapour generated during quarrying operations are usually suspended over a long period in the air. Moreover, particulate matter in the air are capable of being transported from the point of generation to areas far removed (UNEP, 1991b). Once particles of varying chemical compositions are inhaled, they lodge in human lungs; thereby causing lung damages and respiratory problems (Last, 1998). According to Deborah (1996) and National Industrial Sand Association (1997), dusts generated from granite quarrying contain 71 percent silica. Inhaling such dust results in silicosis which is capable of disabling an exposed person and subsequently, leads to death. Apart from silicosis, 
sandblasters, miners and quarry workers are to suffer from pneumoconiosis (www.gulflink.osd.ml).

Suspended particulate matter may be affecting more people globally than any other pollutant on a continuous basis (Richard, et al., 2002). Going by epidemiological studies, a dose-response relationship between exposure to $\mathrm{PM}_{10}$ and respiratory morbidity and mortality are established (Dockery and Pope, 1994; Pope, et al., 1995; Qamar, et al; 2001). Likewise is the role of $\mathrm{PM}_{10}$ in the causation of asthma, lung cancer, cardiovascular issues, and premature death. Even at relatively low concentration (not exceeding standard guideline of $150 \mathrm{ug} / \mathrm{m}^{3}$ for 24 hours), inhalable particulate matter $\left(\mathrm{PM}_{10}\right)$ have adverse effects on human health.

Indeed, an increase of $50 \mathrm{mg} / \mathrm{m}^{3}$ in particulates levels is shown to induce increase death rate from 2 to 8 percent in several countries (Bart, 1993; HEI, 1995). Supporting this particulate level and health relationship, WHO (1994) indicated that daily mortality rates would increase by 20 percent with an increase of particulate level to $200 \mathrm{mg} / \mathrm{m}^{3}$. A report by the Environmental Working Group in California showed that respiratory illnesses caused by particulate matter are responsible for more than 10,000 deaths and 16,000 hospital admissions. The health care cost of these illnesses was put at $\$ 132$ million, in addition to millions of missed work days and school absences each year (www.angelfire.com; Deborah, 1996; Douglas, 1996; USEPA, 1996).

The circumstances surrounding most developing countries, Nigeria inclusive, is more pathetic in view of the utter disregard of pollution limits by most industries, low knowledge of environmental laws, immigration of polluting industries and the general poor living standard which affect people's nutrition status. In most African countries, the risks faced by those who are occupationally exposed and the non-occupationally exposed are poorly research. Of serious concern is the elderly, children and infirmed people who constitute the at-risk population in the various communities hosting quarries. Hence, this study examined the level of suspended particulate matters $\left(\mathrm{PM}_{10}\right)$ within and around selected quarry sites in Abeokuta metropolis. Moreover, it investigated the prevalent health problems suffered by quarry workers and residents of nearby communities. Finally, it assessed the awareness of the negative impacts of living in close proximity to quarry sites among the residents.

\section{Conceptual Framework}

The concept of environmental risk cells (ERCs) provides the conceptual basis for this study. ERCs indicates that in any settlement, human beings are influenced by artificial factors to such an extent that indicators of ill-health can be interpreted by considering their living conditions and lifestyle characteristics. The concept therefore recognizes the important role of human activities in man- environment interaction (Johnston, 1979). As a result of the ecological dominance of humans over the environment, the balance between environmental elements as well as between himself and the environment is altered. The altered environment so created exposes humans to backwash repercussions (Johnston, 1983; Last, 1998; Enger and Smith, 2002) which informed an aggravation of certain illnesses and emergence of new ones.

In a city for instance, the concentration pollutants or hazards create areas or zones of varying risks magnitude (risk cells). The regularity of individual's interaction with such cells (zones) of varying hazards (Shannon and Spurlock, 1976) determines their possibility of contacting diseases. The concept of ERCs assists us to appreciate the fact that particulate matter concentration constitutes hazards to humans that either work at quarry sites or live in close proximity to quarry sites. Different ailments, most especially respiratory diseases are risks to which humans exposed to particulates are likely to contact. Due to the dilution and spread of particulates from quarry sites to other locations, workers at the quarry are expected to experience multiple episodes of respiratory ailments than people that live at distances away from the quarry sites.

Although, the general approach of public health to reducing the burden of respiratory tract infection is hinged on controlling indoor and outdoor air pollution, ERCs concept equally identified frequency of human interaction with zones of high particulates concentration and the distance of human residence to quarry sites as important factors in respiratory diseases intervention.

\section{The Study area}

Quarrying is a very old industry in Nigeria although it remained small and technologically simple until the establishment of the British colonial administration. Quarrying of sand, gravel and building stones is widespread because it is less capital intensive compared to mineral extraction. Furthermore, there is 
widespread distribution of quarry materials; particularly granite in parts of Nigeria (Areola, 1991).

Abeokuta is an ancient city located in the South-western part of Nigeria. The landscape is undulating with most parts littered with rock outcrops. This perhaps informed the choice of the name Abeokuta, meaning "under the rock" in Yoruba language. No doubt, the name is a reflection of how the massive rock feature of the city provided refuge for the ancient dwellers during the inter-tribal wars in the early $19^{\text {th }}$ century. Generally, Abeokuta shares from the widespread deep rock weathering which characterizes the humid tropical region (Areola, 1991). Rocks in Abeokuta are mainly quartzite gneiss complex which is a good material for quarrying. The abundance of granite in Abeokuta is responsible for the large number of quarry companies operating around the city. In addition, the availability of stand-by market within the city as a result of rapid urban expansion and the high demand for construction materials in Lagos city (commercial capital of Nigeria), which is located less than $80 \mathrm{~km}$ away from Abeokuta.

The major quarrying companies identified by the Federal Geological Survey Department (FGSD) includes, Guffanti Nigeria Plc, Associated Granite Industries, Fijabi Adebo Holdings, Obasanjo Holdings, P.W Nigeria Ltd, Veritas Mining Ltd, Bormadek Quarries, Equations Nigeria Ltd, Chinese Quarry, Green palm Quarry, Kassagrand Quarry, and Multiverse Quarry.

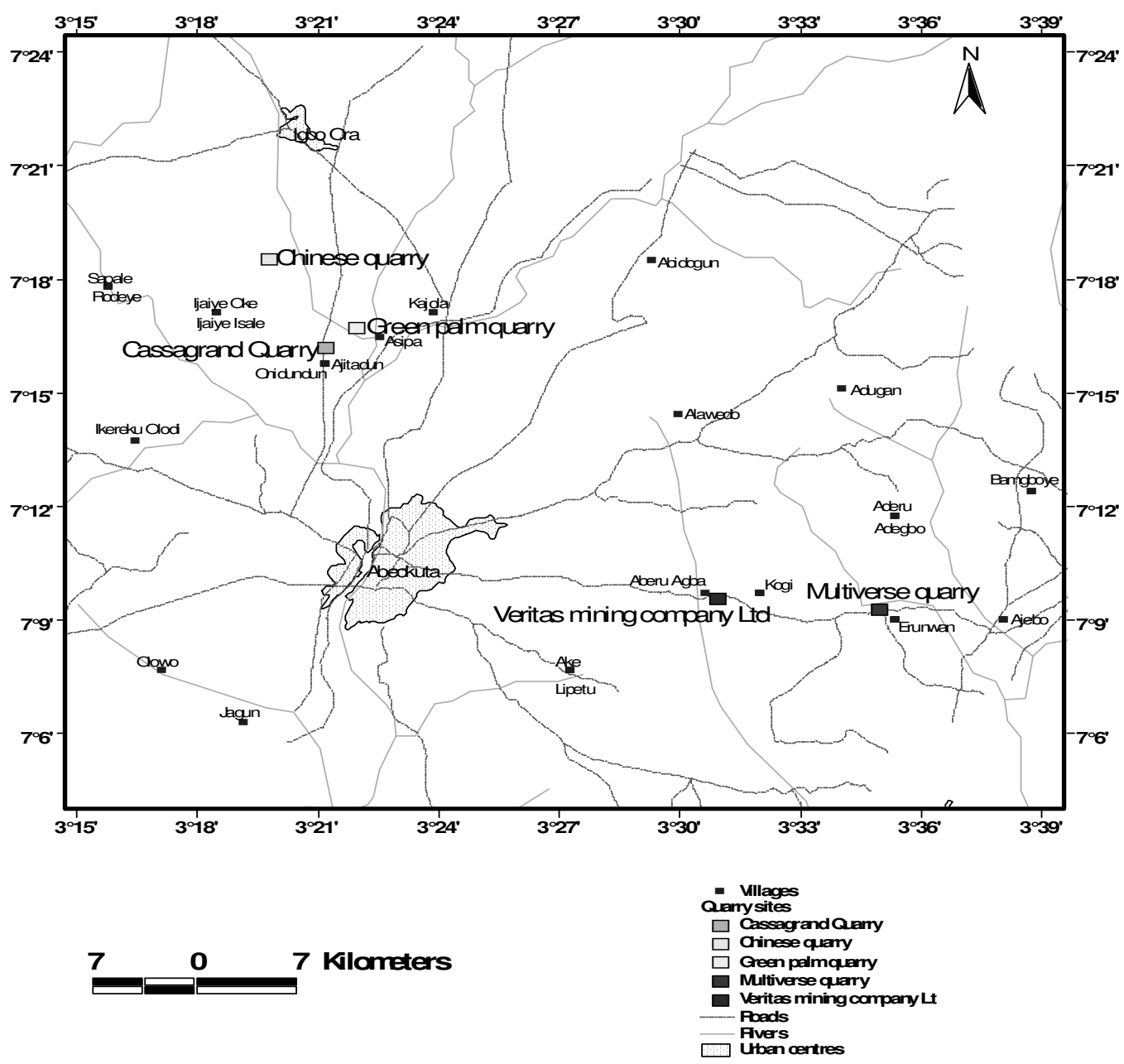

Fig.1:Location of Selected Quarries in Abeokuta 


\section{Materials and methods}

Five quarries were selected among those registered by FGSD in Abeokuta for particulate matter monitoring. These are Chinese Quarry, Veritas Mining Ltd, Green-palm Quarry, Kassagrand Quarry, and Multiverse Quarry (Figure 1). The $\mathrm{PM}_{10}$ monitoring was conducted with the aid of a Suspended Particulate Matter (SPM) meter that measures the concentration of particulates present in the air $\left(\mathrm{mg} / \mathrm{m}^{3}\right)$. The readings were taken as composite at four different points (cardinal directions) so as to arrive at a mean value for a specific sampling location. Particulate concentration at the drilling and crushing operation areas were monitored and also at 5 metres, 10 metres and 25 metres away from these two major operation areas. Furthermore, one of the quarry companies, which granted permission to access medical records of its employees, was selected for the survey of health problems suffered by quarry workers. Five health problems diagnosed among each of the 20 sampled workers (50 percent) were recorded. The specific information retrieved from the medical record of selected employees includes; age, sex, job specification, and the last five ailments diagnosed for each of them.

Finally, well structured and pre-tested questionnaire was administered to sixty-five residents randomly selected from two communities hosting quarries. While forty respondents were sampled from the first community, twenty-five residents were interviewed in the second community based on difference in their area coverage. Questions were asked on residents' socio-demographic characteristics, residency period in the community, perception about quarrying activities in the area and their health experiences. Data generated from these sources were analyzed with the aid of frequency, mean, analysis of variance (ANOVA) and least significant difference (LSD) using Statistical Package for Social Sciences (SPSS 12.0.1 edition).

\section{Results and Discussion}

Table 1 shows that mean SPM level was highest at Multiverse $\left(26.03 \pm 1.36 \mathrm{mg} / \mathrm{m}^{3}\right)$, followed by Veritas $\left(17.63 \pm 3.28 \mathrm{mg} / \mathrm{m}^{3}\right)$ while the lowest levels were recorded at the remaining three quarries. Mean SPM levels range between $26.03 \pm 1.36 \mathrm{mg} / \mathrm{m}^{3}$ and $11.03 \pm 1.52 \mathrm{mg} / \mathrm{m}^{3}$ at the drilling sites while the range was between $14.09 \pm 2.01 \mathrm{mg} / \mathrm{m}^{3}$ and $7.97 \pm 0.63 \mathrm{mg} / \mathrm{m}^{3}$ at the crushing sites of the quarries. The level of particulate matters generated at each quarry site vary significantly ( $F-$ value $=23.04$ at $\mathrm{p}<0.05$ ). The five quarries were differentiated into three groups by LSD based on their mean SPM levels; Multiverse quarry; Veritas and Chinese quarries; and Kasagrand and Greenpalm quarries.

Moreover, the mean SPM level was higher at the drilling points than the crushing points for all quarries. The variation between the two operation areas was significant at $\mathrm{p}<0.01$. Similarly, there was significant variation $(p<0.01)$ in the levels of SPM between the drilling and crushing operation areas and the selected distances of 5 metres, 10 metres and 25 metres away. SPM levels declined with distance from the two main operation areas (Figure 2A and $2 \mathrm{~B}$ ), but higher than the permissible limit of $150 \mathrm{ug} / \mathrm{m}^{3} \quad\left(\approx 0.15 \mathrm{mg} / \mathrm{m}^{3}\right)$ at all selected locations.

The scale of operation largely influenced the level of dust pollution generated at each of the quarries monitored in this study. Among the activity areas, the drilling site constitutes dust pollution risk zone within quarries (Enger and Smith, 2002). This has implication for the planning of mitigation measures within the quarry and the surrounding environment.

The socio-demographic characteristics of the nearby residents (Table 2) reveal that 80 percent are within ages 20 to 50 years. About half of the residents are farmers while 29.2 percent are traders. With respect to educational status, 49.2 percent have no formal education while another 30.8 percent have primary education. Moreover, 55.0 percent of the residents earn less than N5,000 monthly.

The poor socio-economic status of residents living in close proximity to quarry sites may portend a negative implication for proper awareness of pollution arising from quarrying and the required capability to demand for compensation and or the relocation of their settlements farther away from the quarry site.

Table 3 shows that most residents $(80.0$ percent) live in houses situated less than 100 metres away from the quarry sites. For about 60.0 percent of the respondents whose residency preceded the advent of quarry operations, they perceived quarry locations as inappropriate.

In Table 4, frequent generation of dust from the quarries (73.8 percent) was the most outstanding negative impact of quarrying operations identified by the respondents. Other problems identified include noise and ground vibration. The ability of the residents of 
communities living near quarry sites to identify the problems itemized above and their frequency of occurrence showed that they were aware of some negative consequences of quarrying operations on their well-being.

The most prevalent health problem of the nearby residents was identified as nasal infection (29.3 percent) as shown in Table 5. Similarly, among the quarry workers, the common health problems diagnosed are cough (26.0 percent), followed by catarrh (20.0 percent) and sinusitis (15.0 percent) while silicosis recorded the least number of cases (Table 7). There was no significant variation in the ailments suffered by quarry workers $(p>0.05)$. Again, there are similarities in the health problems suffered by the residents living near quarry sites and quarry workers in the study area.

The health problems suffered by the residents are those that associate with inhalation of dust in the air. This finding agrees with the reports of authors such Murray and Lopez (1996), Natural Resources Defense Council (NRDC, 1996) and Enger and Smith (2002). A few of the respondents experience shock due to sudden noise from the use of explosives and ground vibration that result from rock blasting. According to reports, the detonation of explosives in quarrying operation causes ground vibration, which produces effects such as stress, anxiety, increased pulse rate, loss of sleep, fatigue and excessive contraction of pupil among residents living near quarry site (Salvato, 1992., Alloway and Ayres, 1995).

Similarly, the health problems experienced by quarry workers are identical, and are similar to those identified by Murray and Lopez (1996), Dockery and Pope (1994); Pope, et al., (1995) and Peters (1996) in their studies

\section{References}

Alloway, B. J. and Ayres, D. C. (1995). Chemical Principles of Environmental Pollution. Blackie Academic and Professional, London. Pg. 250-290.

Areola, O (1991). Ecology of Natural Resources in Nigeria. Avebury Academic Publishing Group, Aldershot, England. Pp 178-196.

Bart, O. (1993). The Association of air Pollution and Mortality: Examining the case for inference.Archives of Environmental Health, Vol. 48, No. 5, P 336. of the impacts of dust pollution on exposed subjects.

\section{Conclusion}

Granite quarrying has been shown as a human activity that generates particulates pollution in the environment. The high level of particulates generated at the drilling and crushing areas depicts them as hazard zones. Moreover, exposure of quarry workers to particulate pollution, coupled with the general non-use of protection gadgets predispose them to several respiratory ailments similar to health problems found prevalent among residents living near quarry sites.

Considering the various health risks associated with inhalation of particulate matter, environmental impact assessment should be mandated for all quarries. Although quarrying is an age-long economic activity, evidence of its negative impacts should influence more comprehensive environmental policies and strict enforcement of such in the location of quarry sites. Compliance monitoring visits to quarry sites should be done routinely so as to minimize the negative effects of quarrying operations on human health and the environment.

Quarry companies should be mandated to adopt modern technology of dust strapping such that a negligible quantity of dust escapes from the various operations at quarry site. Particulates release can be controlled with scrubbers, precipitators, and filters, which can be retrofitted to dust-stacks for pollutants removal from emissions.

Finally, use of protective gadgets by workers at quarry site should be enforced by the Health and Safety unit or the Management of every quarry company. This is in view of the fact that most workers consider wearing protective gadget while at work an unnecessary burden.

Deborah, S. (1996). Breathtaking: premature Mortality due to Particulate air pollution in 239

America Cities. Natural Resources Defence Council, New York. Pp 14-15.

Douglas, D. (1996). Health effects of Acid Aerosols on North America Children: Respiratory symptom. Environmental Health Perspectives, Vol. 104, No. 5 P 503.

Dockery, D., Pope, C. (1994). 'Acute respiratory effects of particulate air pollution'. Annual Review of Public Health. Vol.15, pp.107132. 
Enger, E.D and Smith, B.F (2002). Environmental Science: A study of Interrelationship ( $8^{\text {th }}$ edition $) \quad$ McGraw-Hill Higher Education, New York Pp372 -377. Health Effects Institute - HEI (1995). Particulate Air Pollution and Daily Mortality: Replication and Validation of selected studies HEI Cambridge, MA. P 4.

Johnston, R.J (1979). Geography and Geographers. London: Edward Arnold P32.

Johnston, R.J (1983). Philosophy and Human Geography: An Introduction to contemporary approaches. London: Edward Arnold, 153p. Murray, C.J.L. and Lopez, A.D (1996a). Global Health Statistics: a compendium of incidence, prevalence and mortality estimates for over 200 conditions. Cambridge, M. A. Harvard

University Press.

UNEP (1991b). Urban air Pollution. In: Environment Library, No. 4, Nairobi: UNEP. USEPA (1996). Review of National Ambient Air Quality standards for Particulate Matter: Policy Assessment of scientific and Technician information, Report No. EPA- 452/R-96-013 (USEPA, Washington D.C) Pp V-20 -V-24, V27, V-28 \& V-71.

USEPA (2008). Region 4: Laboratory and Field operations - PM 2.5: Objectives and History. As available at en.wikipedia.org/wiki/particulate

Last, J.M. (1998). Public Health and Human Ecology (2 ${ }^{\text {nd }}$ Edition) McGraw-Hill Medical Publishing Prentice-Hall Int. Edition Canada. Pp153-200.

National Industrial Sand Association (1997). Respiratory Health Effects of Crystalline Silica. As available at www.riccisand.com/health.

Natural Resources Defense Council- NRDC (1996). Air Pollution. In: Our Children at RiskThe 5 Worst Environmental Threats to their Health. www.nrdc.org/health/kids/ocarl
Peters, A. (1996). Acute Effects of Exposure to high levels of Air pollution in Eastern Europe. American Journal of Epidemiology, Vol. 144, No. 6. Pg. 570-580.

Pope, C., Bate, D.V. and Razienne, M.E. (1995). Health effects of Particulates in air pollutant: Time for re-assessment?

Environmental Health perspective. 103: 472475.

Qamar, R., Paul, N., Kirk, R.S., Prahlad, K.S. and James S. (2001). International Conference on Environmental and occupational Lung Diseases. Environmental Health Perspectives Vol. 109 No. 4, April 2001. Pp 425-431. Richard, T., Michael, J., Eugenia, E., Daniel, K., Kazuhiko, I. and George, D. (2002). Lung cancer, Cardiovascular mortality and lung-term exposure to fine particulate air pollution. Journal of American Medical Association. Vol. 287, No. 9

Salvato, J. A. (1992). Environmental Engineering and Sanitation. $4^{\text {th }}$ Edition - John Wiley and Sons Incorporated. Pg. 767- 806.

Shannon, G.W and Spurlock, C. (1976). "Urban Ecological containers, Environmental Risk Cells and the use of Medical Services." Presented at the Annual Meeting of the A.A.G, New York City.

World Health Organisation (1994). Update and Revision of the Air quality guidelines for Europe.

WHO Regional Office for Europe. Report No. EUR/ICP/EHAZ 94-05/PB01. Pg. 14.

www.edugreen.teri.res.in/explore/air/air.htm

www.angelfire.com. Pointpaper on Basalt Quarry- White Cove, Nova Scotia www.gulflink.osd.ml/particulate 
Table 1: Mean levels of Particulate Matters $\left(\mathrm{mg} / \mathrm{m}^{3}\right)$ in the selected Quarries

\begin{tabular}{lcccc}
\hline $\begin{array}{l}\text { Quarry } \\
\text { 1. Chinese }\end{array}$ & $0 \mathrm{~m}$ & $5 \mathrm{~m}$ & $10 \mathrm{~m}$ & $25 \mathrm{~m}$ \\
$\quad$ & & & \\
$\quad$ Drilling site & $14.34 \pm 1.20$ & $7.70 \pm 1.24$ & $6.01 \pm 0.01$ & $4.85 \pm 0.20$ \\
Crushing site & $11.01 \pm 1.27$ & $5.57 \pm 0.76$ & $6.01 \pm 0.01$ & $4.85 \pm 0.20$ \\
& & & & \\
2. Greenpalm & & & & \\
$\quad$ Drilling site & $11.03 \pm 1.52$ & $6.83 \pm 0.49$ & $5.97 \pm 0.05$ & $4.23 \pm 0.20$ \\
Crushing site & $7.97 \pm 0.63$ & $5.88 \pm 0.50$ & $6.00 \pm 0.01$ & $4.23 \pm 0.20$
\end{tabular}

\section{Kasagrand}

$\begin{array}{lrrrr}\text { Drilling site } & 11.03 \pm 1.52 & 6.91 \pm 0.52 & 5.95 \pm 0.06 & 4.03 \pm 0.06 \\ \text { Crushing site } & 9.54 \pm 0.77 & 6.59 \pm 1.66 & 5.96 \pm 0.05 & 4.03 \pm 0.06\end{array}$

4. Veritas

$\begin{array}{lllll}\text { Drilling site } & 17.63 \pm 3.28 & 9.67 \pm 1.66 & 5.88 \pm 0.02 & 3.67 \pm 0.40 \\ \text { Crushing site } & 11.91 \pm 1.82 & 8.59 \pm 0.89 & 6.02 \pm 0.01 & 3.67 \pm 0.40\end{array}$

5. Multiverse

\begin{tabular}{lcccc} 
Drilling site & $26.03 \pm 1.36$ & $14.70 \pm 1.66$ & $5.73 \pm 0.04$ & $3.70 \pm 0.40$ \\
Crushing site & $14.09 \pm 2.01$ & $9.85 \pm 1.59$ & $5.58 \pm 0.02$ & $3.70 \pm 0.40$ \\
Particulate matter Standard $150 \mathrm{ug} / \mathrm{m} 3$ & (24 hours) and 50ug/m3 (annual average) & \\
\hline
\end{tabular}

* National Ambient Air Quality Standards (2005), U.S Environmental Protection Agency (2008) 


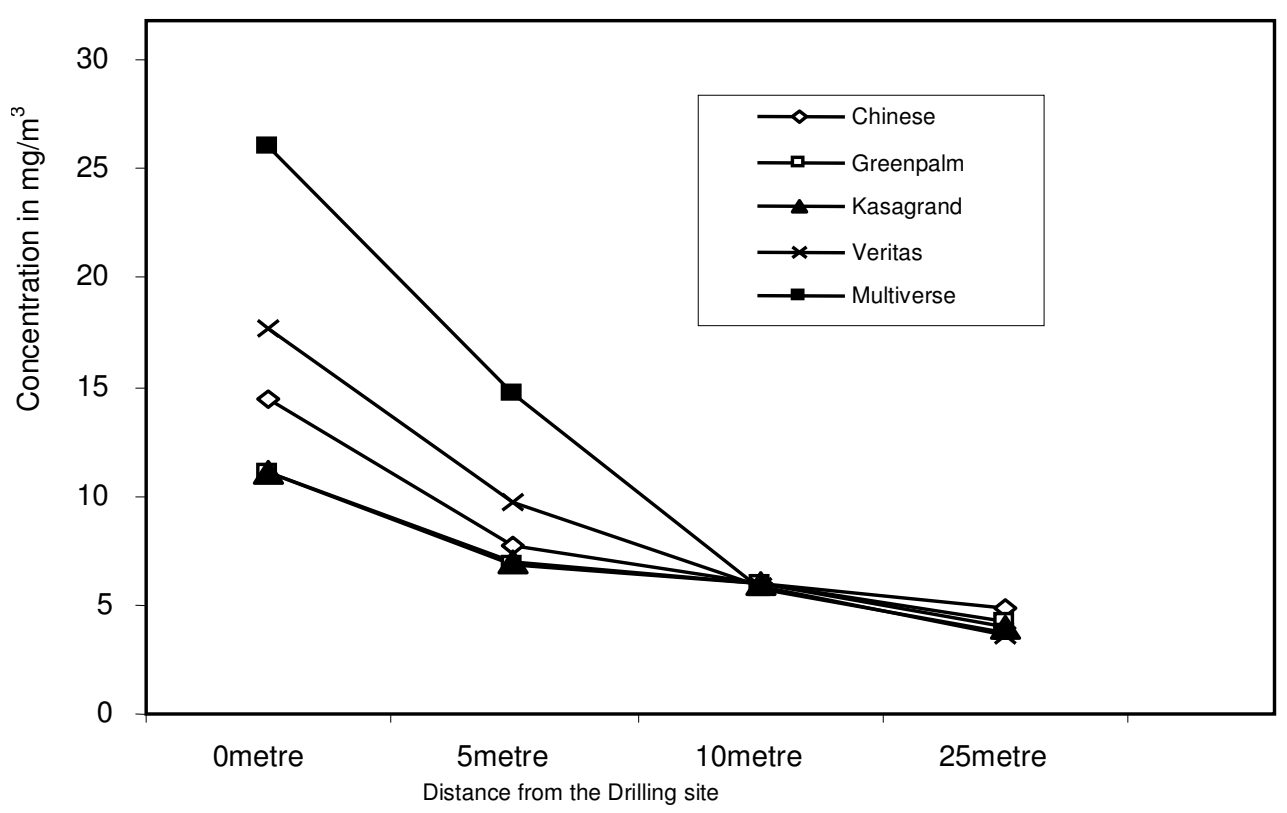

Figure 2A: Concentration of SPM at selected distances from the drilling site

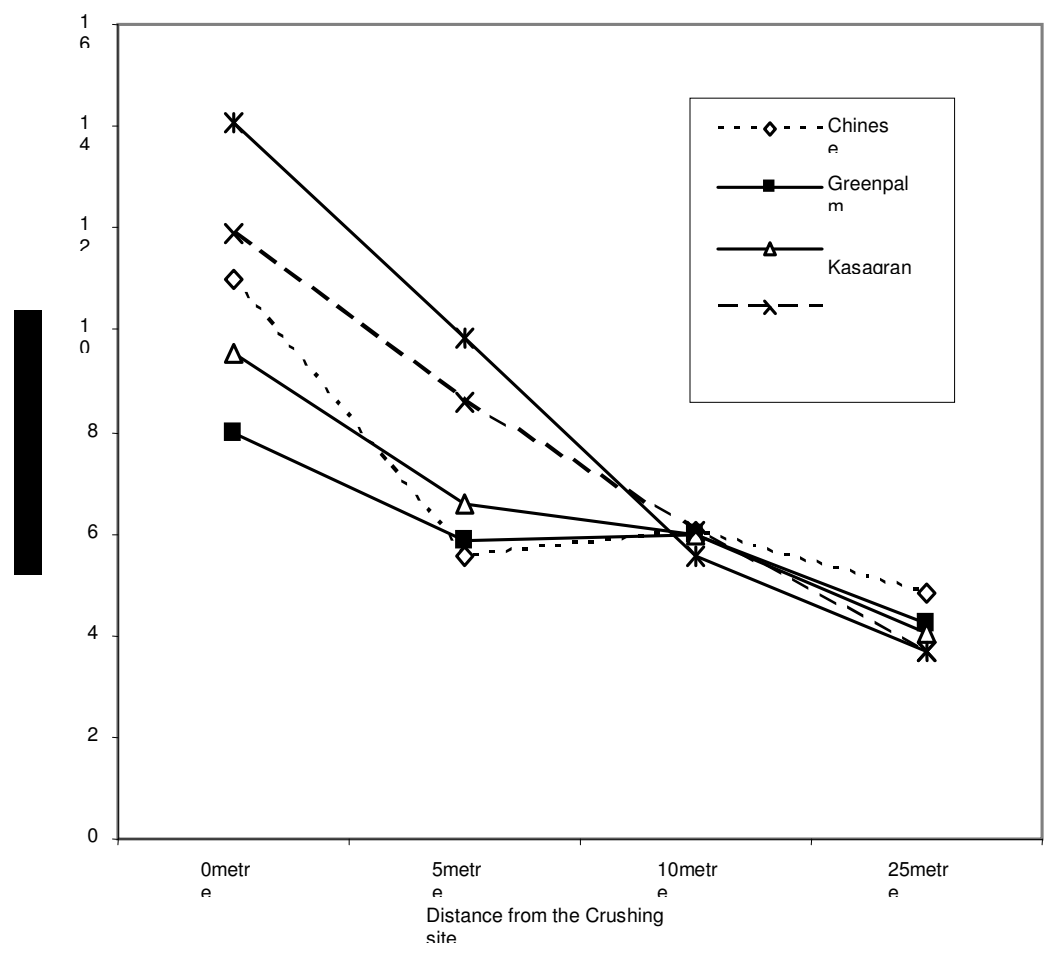

Figure 2B: Concentration of SPM at selected distances from the crushina site 
Table 2: Socio-demographic characteristics of residents living near Quarry site

\begin{tabular}{|c|c|c|}
\hline Characteristics & No. of Respondents & Percent \\
\hline \multicolumn{3}{|l|}{ Age-group } \\
\hline $20-35$ years & 28 & 43.1 \\
\hline $36-50$ years & 24 & 36.9 \\
\hline $51-65$ years & 11 & 16.9 \\
\hline Above 65 years & 2 & 3.1 \\
\hline Total & 65 & 100.0 \\
\hline \multicolumn{3}{|l|}{ Sex } \\
\hline Male & 38 & 58.5 \\
\hline Female & 27 & 41.5 \\
\hline Total & 65 & 100.0 \\
\hline \multicolumn{3}{|l|}{ Occupation } \\
\hline Civil servants & 6 & 9.2 \\
\hline Professionals & 2 & 3.1 \\
\hline Artisans & 10 & 15.4 \\
\hline Farmers & 28 & 43.1 \\
\hline Traders & 19 & 29.2 \\
\hline Total & 65 & 100.0 \\
\hline \multicolumn{3}{|l|}{ Education Status } \\
\hline No. formal education & 32 & 49.2 \\
\hline Primary education & 20 & 30.8 \\
\hline Secondary education & 9 & 13.8 \\
\hline Post secondary education & 4 & 6.2 \\
\hline Total & 65 & 100.0 \\
\hline \multicolumn{3}{|l|}{ Income } \\
\hline$<\mathrm{N} 5,000$ & 36 & 55.4 \\
\hline $\mathrm{N} 5,000-\mathrm{N} 15,000$ & 24 & 36.9 \\
\hline $\mathrm{N} 16,000-\mathrm{N} 30,000$ & 4 & 6.2 \\
\hline$>\mathrm{N} 30,000$ & 1 & 1.5 \\
\hline Total & 65 & 100.0 \\
\hline
\end{tabular}


Table 3: Residency duration, Distance to quarry and Observed impacts of quarry operations

\begin{tabular}{lcc}
\hline Exposure factors & No. of Respondents & Percent \\
Residency duration & & \\
1-5 years & 9 & 13.8 \\
6-10 years & 16 & 24.1 \\
11-15 years & 13 & 20.7 \\
16-20 years & 5 & 6.9 \\
$>20$ years & 22 & 34.5 \\
Total & 65 & 100.0 \\
Distance to Quarry site & 52 & \\
$<100$ metres & 9 & 80.0 \\
100-250 metres & 3 & 13.8 \\
$251-500$ metres & 1 & 4.6 \\
$500-1000$ metres & 65 & 1.6 \\
Total & & 100.0 \\
\hline
\end{tabular}

Table 4: Negative Effects of Quarrying observed by nearby Residents

\begin{tabular}{lcc}
\hline Quarrying Impact & No. of Respondents & Percent \\
Observed effects & & \\
Noise and ground Vibration & 26 & 40.0 \\
Noise alone & 19 & 29.3 \\
Air pollution by dust & 8 & 12.3 \\
Ground vibration alone & 6 & 9.2 \\
No felt problem & 6 & 9.2 \\
Total & 65 & 100.0 \\
Frequency of dust generation & 48 & \\
Frequently & 12 & 73.8 \\
Occasionally & 4 & 18.5 \\
Daily & 1 & 6.2 \\
Weekly & 65 & 1.5 \\
Total & & 100.0 \\
\hline
\end{tabular}

Table 5: Health problems experienced by residents living near quarry site

\begin{tabular}{lcc}
\hline Health problems & No. of Respondents & Percent \\
Ailment reported to Clinic & 19 & \\
Nasal infection & 3 & 29.3 \\
Shock & 4 & 4.6 \\
Cough & 39 & 6.1 \\
Others & 65 & 60.0 \\
Total & & 100.0 \\
Ailment suffered by other family members & \\
Catarrh & 18 & 78.3 \\
Hearing impairment & 1 & 4.3 \\
Nasal infection & 3 & 13.1 \\
Asthma & 1 & 4.3 \\
Total & 23 & 100.0 \\
\hline
\end{tabular}


Table 6: Age- group and Job Specification of sampled Quarry workers

\begin{tabular}{|c|c|c|c|c|c|c|c|}
\hline \multicolumn{3}{|c|}{ Characteristics of Quarry workers } & \multicolumn{4}{|c|}{ No. of respondents } & Percent \\
\hline $\begin{array}{l}\text { Age-group } \\
20-35 \text { years } \\
36-50 \text { years } \\
>50 \text { years } \\
\text { Total }\end{array}$ & & & & $\begin{array}{r}11 \\
8 \\
1 \\
20\end{array}$ & & & $\begin{array}{c}55.0 \\
40.0 \\
5.0 \\
100.0\end{array}$ \\
\hline $\begin{array}{l}\text { Job specification } \\
\text { Drillers } \\
\text { Blasters } \\
\text { Crusher operators } \\
\text { Crusher mechanics } \\
\text { Total }\end{array}$ & & & & $\begin{array}{l}9 \\
6 \\
3 \\
2 \\
20\end{array}$ & & & $\begin{array}{l}45.0 \\
30.0 \\
15.0 \\
10.0 \\
100.0\end{array}$ \\
\hline Health problem & First & Second & Third & Fourth & Fifth & Overall & Percent \\
\hline Cough & 4 & 4 & 4 & 7 & 7 & 26 & 26.0 \\
\hline Acute malaria & 4 & 3 & 7 & 4 & 3 & 21 & 21.0 \\
\hline Catarrh & 2 & 3 & 5 & 5 & 5 & 20 & 20.0 \\
\hline Sinusitis & 7 & 3 & 1 & 2 & 2 & 15 & 15.0 \\
\hline Gastro-intestinal infection & 1 & 3 & 0 & 2 & 3 & 9 & 9.0 \\
\hline Fungal dermatitis & 1 & 2 & 1 & 0 & 0 & 4 & 4.0 \\
\hline Malaise & 0 & 1 & 1 & 0 & 0 & 2 & 2.0 \\
\hline Hypertension & 1 & 1 & 0 & 0 & 0 & 2 & 2.0 \\
\hline Silicosis & 0 & 0 & 1 & 0 & 0 & 1 & 1.0 \\
\hline Total & 20 & 20 & 20 & 20 & 20 & 20 & 100.0 \\
\hline ANOVA result & 1.76 & 0.62 & 0.52 & 0.79 & 0.09 & & \\
\hline
\end{tabular}

